\title{
Cyanide in Cassava: A Review
}

\section{Njoku Damian Ndubuisi*, Ano Chukwuka Ugochukwu Chidiebere}

National Root Crops Research Institute Umudike, Nigeria

*Corresponding author: Njoku Damian Ndubuisi, National Root Crops Research Institute Umudike, Umudike, PMB 7006 Umuahia, Abia State, Nigeria. Tel: +2348034432883; Email: njokudn2012@gmail.com

Citation: Ndubuisi ND, Chidiebere ACU (2018) Cyanide in Cassava: A Review. Int J Genom Data Min 02: 118. DOI: $10.29011 / 2577-0616.000118$

Received Date: 07 December, 2017; Accepted Date: 10 January, 2018; Published Date: 09 February, 2018

\begin{abstract}
The work presented here is a review of cyanide in cassava. The presence of the two cyanogenic glycosides (linamarin and lotaustralin), in cassava, which on enzymatic hydrolysis leads to the production of hydrogen cyanide, is a major factor limiting cassava use as food or feed. Linamarin accounts for more than $80 \%$ of the cassava cyanogenic glucosides. It is a $\beta$-glucoside of acetone cyanohydrin and ethyl-methyl-ketone-cyanohydrin. Cassava varieties are often categorized as either sweet or bitter, signifying the absence or presence of toxic levels of cyanogenic glucosides, respectively. The so-called sweet (actually not bitter) cultivars can produce as little as 20 milligrams of Cyanide (CN) per kilogram of fresh roots, whereas bitter ones may produce more than 50 times as much $(1 \mathrm{~g} / \mathrm{kg})$. Cassava grown during drought are especially high in these toxins. In addition, Cyanide is a chemical defense developed to cope with a huge diversity of unfavorable biotic conditions in the field. These glycosides and cyanogenic glycosides liberate cyanide, which, blocking cytochrome c oxidase (responsible for muscle and brain function) and NIS, is poisonous to parasites and herbivores but does not affect the plant cells. A lot of factors affect the level of cyanogenic glycosides in cassava. Many processing methods that reduce cyanide levels in cassava products have been developed.
\end{abstract}

Keywords: Cassava; Cyanogenic; Hydroxynitrite; Linamarin

\section{Introduction}

Cassava (Manihot esculenta Crantz) is an important tropical root crop providing energy to about 500 million people [1,2] Almost all the cassava produced is used for human consumption and less than 5 percent is used in industries. As a food crop, cassava fits well into the farming systems of the smallholder farmers in Nigeria because it is available all year round, thus providing household food security. Compared to grains, cassava is more tolerant to low soil fertility and more resistant to drought, pests and diseases. Furthermore, its roots store well in the ground for months after maturity. Cassava is important, not just as a food crop but even more so as a major source of cash income for producing households. As a cash crop, cassava generates cash income for the largest number of households, in comparison with other staples, contributing positively to poverty alleviation. The presence of cyanogenic glycosides in cassava which when broken down through enzymatic reaction librates hydrogen cyanide poses a great concern in cassava utilization as food and as industrial raw material.

With respect to Cyanide levels, cassava varieties are broadly divided into two groups; the sweet cassava known for low cyanide content and the bitter cassava with its high characteristic content of Cyanogenic Glycosides (CGs) that is highly toxic when consumed [3-5]. Total cyanide in cassava products exists in form of CGs (linamarin and lotaustralin), cyanohydrin and free hydrocyanic acid (HCN). Notwithstanding the CGS, according to FAO, FAO, 2001 [6] 172 million tons of cassava were produced world-wide in 2000 with Africa accounting for 45\%, Asia 28\% and Latin America and the Caribbean $19 \%$. The five main producing countries are Nigeria, Brazil, Thailand, Congo (DRC) and Indonesia.

The on-going challenge is to ensure that the presence of these cyanogenic glycosides is minimized through proper understanding and possibly control of factors that affect cyanogenic glycoside content of cassava. Roots and leaves contain the highest amount of linamarin [7].

\section{Cyanide in Plants}

The cyanogenic glycosides are a group of nitrile-containing plant secondary compounds that yield cyanide (cyanogenesis) following their enzymatic breakdown. The functions of cyanogenic glycosides remain to be determined in many plants; however, in some plants they have been implicated as herbivore deterrents and as transportable forms of reduced nitrogen [8-10]. It is 
Citation: Ndubuisi ND, Chidiebere ACU (2018) Cyanide in Cassava: A Review. Int J Genom Data Min 02: 118. DOI: 10.29011/2577-0616.000118

estimated that between 3,000 and 12,000 plant species produce and sequester cyanogenic glycosides. The major edible plants in which cyanogenic glycosides occur are almonds, sorghum, cassava, lima beans, stone fruits and bamboo shoots [11,12]. In certain sapindaceous seeds, HCN may arise during cyanolipid hydrolysis. More frequently, HCN production in higher plants results from the catabolism of cyanogenic glycosides. The approximately 75 documented cyanogenic glycosides are all $\mathrm{O}-\beta$-glycosidic derivatives of ahydroxynitriles. Depending on their precursor amino acid, they may be aromatic, aliphatic, or cyclopentenoid in nature. Most are cyanogenic monosaccharides in which the unstable cyanohydrin moiety is stabilized by glycosidic linkage to a single sugar residue. Alternatively, in the cyanogenic disaccharides [e.g. (R)-amygdalin, (R)-vicianin, and linustatin] or trisaccharides (e.g. xeranthin), two or three sugar moieties, respectively, are involved in such stabilization. Sulfated, malonylated, and acylated derivatives of cyanogenic glycosides are also known. are also known. Cyanogenesis is not exclusive to those plant species accumulating cyanolipids and cyanogenic glycosides. All higher plants probably form low levels of $\mathrm{HCN}$ as a coproduct of ethylene biosynthesis [13]. This might explain why even 'acyanogenic' plants contain significant levels of the cyanide detoxifying enzyme $\beta$-cyanoalanine synthase. Cyanogenesis is also known in animals, but is restricted to the arthropods, notably to certain centipedes, millipedes, and insects. In fungi and bacteria, HCN may originate via oxidative decarboxylation of glycine.

A cyanogenic food of particular economic importance is cassava (Manihot esculenta), which is also known by the names manioc, yuca and tapioca. Cassava is by far the most important cyanogenic food crop for humans and is an important source of dietary energy in tropical regions. The predominant cyanoglycoside in cassava is linamarin. It is present in leaves and tubers, both of which are eaten. Linamarin is also present in beans of the lima or butter type. Amygdalin is the cyanogenic glycoside responsible for the toxicity of the seeds of many species of Rosaceae, such as bitter almonds, peaches and apricots. Sweet almonds are low in amygdalin as a result of breeding processes. Their use in marzipan is common but the preparation procedure should eliminate most of the cyanide. Cyanogen levels can vary widely with cultivar, climatic conditions, plant part and degree of processing. Typical levels for some plant materials consumed by humans are found in (Table 1) below:

\begin{tabular}{|c|c|c|}
\hline Food & $\begin{array}{c}\text { Major cyanogenic } \\
\text { glycosides present }\end{array}$ & $\begin{array}{c}\text { Cyanogen } \\
\text { content } \\
\text { (mg HCN/kg) }\end{array}$ \\
\hline $\begin{array}{c}\text { Cassava (Manihot } \\
\text { esculenta) - root }\end{array}$ & Linamarin & $15-1000$ \\
\hline $\begin{array}{c}\text { Sorghum (Sorghum } \\
\text { vulgare) - leaves }\end{array}$ & Dhurrin & $750-790$ \\
\hline
\end{tabular}

\begin{tabular}{|c|c|c|}
\hline $\begin{array}{c}\text { Flax (Linum } \\
\text { usitatissimum) - seed } \\
\text { meal }\end{array}$ & Linamarin, linustatin, & $360-390$ \\
\hline & Neolinustatin & \\
\hline $\begin{array}{c}\text { Lima beans (Phaseolus } \\
\text { lunatus) }\end{array}$ & & $2000-3000$ \\
\hline $\begin{array}{l}\text { Giant taro (Alocasia } \\
\text { macrorrhizos) - leaves }\end{array}$ & Triglochinin & $29-32$ \\
\hline $\begin{array}{c}\text { Bamboo (Bambusa } \\
\text { arundinacea) - young }\end{array}$ & Taxiphyllin & $100-8000$ \\
\hline Shoots & & \\
\hline $\begin{array}{l}\text { Apple (Malus spp.) - } \\
\text { Seed }\end{array}$ & Amygdalin & $690-790$ \\
\hline $\begin{array}{c}\text { Peach (Prunus persica) } \\
\text { - Kernel }\end{array}$ & Amygdalin & $710-720$ \\
\hline \multirow[t]{3}{*}{$\begin{array}{c}\text { Apricot (Prunus } \\
\text { armeniace) - Kernel }\end{array}$} & Amygdalin & $785-813$ \\
\hline & & $89-2170$ \\
\hline & & 2.2 (juice) \\
\hline $\begin{array}{c}\text { Plum (Prunus spp.) - } \\
\text { Kernel }\end{array}$ & Amygdalin & $696-764$ \\
\hline $\begin{array}{c}\text { Nectarine (Prunus } \\
\text { persica var } \\
\text { nucipersica) - }\end{array}$ & Amygdalin & $196-209$ \\
\hline \multicolumn{3}{|l|}{ Kernel } \\
\hline Cherry (Prunus spp.) & Amygdalin & 4.6 (juice) \\
\hline $\begin{array}{l}\text { Bitter almond (Prunus } \\
\text { dulcis) }\end{array}$ & Amygdalin & 4700 \\
\hline \multicolumn{3}{|c|}{$\begin{array}{l}\text { Cited from Haque and Bradbury, } 2002[14] \text {; Simeonova and Fishbein, } \\
\qquad 2004[15]\end{array}$} \\
\hline
\end{tabular}

Table 1: Levels of cyanogenic glycoside present in sampled plants.

In areas of the world where cyanogenic plants such as cassava and lima beans comprise the major item of the diet, chronic cyanide poisoning and associated pathological conditions still exist [16]. It is highly desirable that the toxicity of cyanogenic plants to humans and livestock be reduced. This is achievable by: (a) selective breeding to produce low-cyanogen varieties, as was accomplished for almonds, (b) screening of natural populations for low-cyanogen varieties, (c) mutagenesis of protoplasts or cell cultures with subsequent regeneration of plants having desired mutant genotypes, or (d) genetic engineering.

\section{Role of Cyanogenic Glycosides in Plants}

A common feature of cyanophoric plants is that cyanogenic glycoside hydrolysis occurs at a significant rate only after their tissues have been disrupted by herbivores, fungal attack, or 
mechanical means. Although other explanations are possible, it is generally assumed that the glycosides and their catabolic enzymes are separated in the intact plant by compartmentation at either tissue or subcellular levels [17]. These possibilities have been extensively tested in a single organism, namely the leaves of 6-day old light-grown sorghum seedlings [18]. Somewhat unexpectedly, the authors demonstrated that the substrate and its catabolic enzymes were localized within different tissues. The cyanogenic glycoside dhurrin was sequestered in the vacuoles of epidermal cells, whereas the 3-glycosidase and hydroxynitrile lyase were present almost entirely in the underlying mesophyll cells. These two enzymes were located in the chloroplasts and cytosol, respectively. It therefore seems likely that the large-scale hydrolysis of dhurrin, which probably provides a defense mechanism against herbivores by liberating HCN, occurs only after tissue disruption allows the mixing of contents of different tissues.

Available evidence from other plant species, however, favors compartmentation of components of the 'cyanide bomb' at the subcellular level. In cassava, cells throughout the entire root cross-section possess both cyanogens (principally linamarin) and linamarase [19]. As in sorghum, highest glycoside levels are found in outer cell layers, again suggesting the involvement of cyanogens in defense against herbivores or pathogens, but the subcellular localizations of linamarin and linamarase remain unknown. In Phaseolus lunatus, the low recoveries of linamarin, linamarase, and hydroxynitrile lyase in leaf mesophyll protoplasts pointed to other tissues, perhaps the epidermis, as the principal site for these components [20]. Although these data cannot unequivocally distinguish between an epidermal or mesophyll location, it seems certain that the P. lunatus linamarase is apoplastic. Leaf discs hydrolyzed externally supplied linamarin, and about onethird of the total linamarase activity was extractable by multiple infiltrations of the leaves. The T. repens linamarase was detected by immunocytofluorescence in cell walls, especially those of the epidermis, and in the cuticle. More recently, protoplast isolation and tissue filtration experiments with Hevea endosperm showed that linamarin and the hydroxynitrile lyase were intracellular but that linamarase occurred both intra- and extracellularly. The apoplastic distribution of most linamarases contrasts with the intracellular location of sorghum dhurrinase, a fact perhaps related to the nonglycoprotein character of the latter [17].

The physiological importance of cyanogenic compounds in plant metabolism is currently receiving renewed interest. As with other secondary products, cyanogenics were originally viewed as excretory substances, but their turnover (seasonal and even diurnal) argues strongly against this hypothesis.

Given the well documented toxicity of $\mathrm{HCN}$, a role in plant protection against herbivores, pathogens, and competitors is appealing. Much evidence, indeed, favors a defence function for cyanogenics against certain animals including insects [21].

\section{Cyanide in Cassava}

Of all cyanogenic crops, the most agronomically important, is the tropical root crop, cassava (Manihot esculenta, Crantz). More than 153 million tons of cassava is produced annually, and it is the major source of calories for many people living in the tropics, particularly sub-Saharan Africa [22].

Cassava leaves have higher protein content, contain vitamin $\mathrm{C}$ and vitamin A and provide some dietary fiber [23]. Much of the protein in the leaves is made up of linamarase, the enzyme that detoxifies the cyanogenic glycosides in cassava [24]. However, each parts of cassava plants (leaves, stem, root) contains high levels of cyanogenic glycosides; linamarin, lotaustralin, and amygdalin $[25,26]$ (Figure 1), with linamarin been the most predominant cyanogen. Linamarin is rapidly hydrolyzed by linamarase to glucose, acetone cyanohydrin, and hydrogen cyanide.

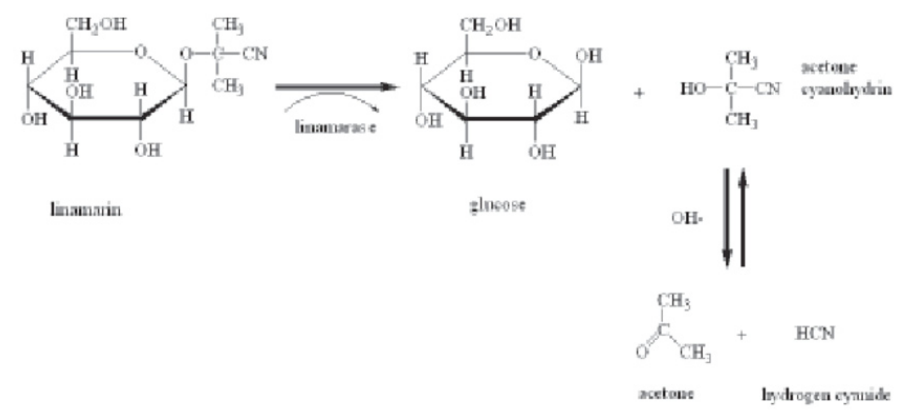

Figure 1: Hydrolysis of Linamarin to produce cyanide (Cited from Lykkesfeldt and Moller, 1994; Bolarinwa et al., 2016).

Under neutral conditions, acetone cyanohydrin decomposes to acetone and hydrogen cyanide.

The cyanide level of cassava varies from about 75 to 350 ppm but can be up to 1000 ppm or more depending on the variety, plant age, soil condition, fertilizer application, weather, and other factors [27-29]. Studies have shown that the levels of cyanogenic glycosides in cassava roots are generally lower than that in the leaves and stems [30,31]. Cassava roots have been reported to contain cyanide content of $10-500 \mathrm{mg} / \mathrm{kg}$ of dry matter [32] and the leaves were reported to contain 53-1300 cyanide equivalents/ $\mathrm{kg}$ of dry matter [33].

Cassava cultivars are classified as "bitter" or "sweet" depending on the level of cyanogenic glucoside (hence hydrogen cyanide). Values from $15-400 \mathrm{mg}$ of hydrogen cyanide per kilogram of fresh weight of cassava roots have been reported for bitter varieties. Sweet varieties of cassava (low cyanide content) will typically contain approximately $15-50 \mathrm{mg}$ hydrogen cyanide/ $\mathrm{kg}$ fresh cassava. Sweet varieties of cassava can be processed adequately by peeling and roasting, baking or boiling, while bitter varieties of cassava (high cyanide content) require more extensive processing such as drying, fermentation etc. Bitter cassava varieties 
are more drought resistant and thus more readily available and cheaper. However, owing to food shortage in times of drought, less time is available for the additional processing required for cassava products. Highly toxic hydrocyanic acid (HCN) is released from the cyanogenic glucosides during hydrolysis by the enzyme linamarase (present in the root peel of cassava).

The World Health Organisation (WHO) has set the safe level of cyanogens in cassava flour at $10 \mathrm{ppm}$ or $10 \mathrm{mg} \mathrm{HCN} / \mathrm{kg}$, while in Indonesia the acceptable limit is $40 \mathrm{ppm}$ [34-37]. Consumption of cassava and its products that contain large amounts of cyanogens may cause cyanide poisoning with symptoms of vomiting, nausea, dizziness, stomach pains, weakness, headache, exacerbates goitre and diarrhoea and occasionally death [37-47].

Although processing methods can reduce linamarin and cyanide in food, improperly processed cassava products would contain some amount of residual linamarin and hydrogen cyanide. This would result in the potential toxicity of the cassava products. Indeed, cases of cyanide toxicity from the consumption of inadequately processed cassava products have been reported [40].

\section{Factors Affecting Cyanide Content of Cassava}

\section{Cultivar}

Thousands of cassava cultivars have been developed that are adapted to local conditions and differ in their ability to tolerate pest and diseases, yield, nutritional and cooking qualities of food products. Cassava is propagated clonally from stem cuttings so there is minimal variation between individuals of one cultivar when grown under the same environmental conditions. All cassava cultivars contain cyanogenic glucosides, however, a wide variation in the concentration of cyanogens exists among different cultivars. This can range from 1 to $2,000 \mathrm{mg} / \mathrm{kg}$ [37]. Cultivars with $100 \mathrm{mg} /$ $\mathrm{kg}$ are called bitter [43]. A study in Fiji by [44] on 17 different cultivars grown in the same environmental confirmed the influence of cassava variety on levels of cyanogenic glucosides (and hence hydrogen cyanide) content. The 17 different cultivars had cyanide levels of $14-121 \mathrm{mg} / \mathrm{kg}$.

\section{Climatic Conditions}

Cassava, a perennial shrub thrives in tropical and subtropical conditions. In general, the crop requires a warm humid climate. Temperature is important, as all growth stops at about $10^{\circ} \mathrm{C}$. Typically, the crop is grown in areas that are frost free the year round. The highest root production can be expected in the tropical lowlands, below $150 \mathrm{~m}$ altitude, where temperatures average $25-27^{\circ} \mathrm{C}$, but some varieties grow at altitudes of up to $1500 \mathrm{~m}$. The plant produces best when rainfall is fairly abundant, but it can be grown where annual rainfall is as low as $500 \mathrm{~mm}$ or where it is as high as $5,000 \mathrm{~mm}$. The plant can stand prolonged periods of drought in which most other food crops would perish. This makes it valuable in regions where annual rainfall is low or where seasonal distribution is irregular. In tropical climates the dry season has about the same effect on Cassava as low temperature has on deciduous perennials in other parts of the world. The period of dormancy lasts two to three months and growth resumes when the rains begin again. Cassava is drought resistant and grows well in poor soil (Java Cassava, 2007). The problem however is that cyanide content of cassava tends to increase during periods of droughts and or prolonged dry weather due to water stress on the plant [24]. For example, in Mozambique, about 55\% of the sweet fresh roots were extremely toxic and the remainder moderately so during drought like conditions. Similar observations were recorded in Democratic Republic of Congo [45], and various citations in Africa. Splittstoesser and Tunya (1992) [46] reported that cassava grown in wet areas contain relatively lower amount of cyanide than those grown in drier areas.

\section{Fertilizer}

There is a general consensus that crop yields do increase with application of fertilizer, there is debate however on the relationship between addition of fertilizer and cyanide content of cassava. Studies in the Philippines [47] concluded that application of fertilizer does not significantly affect cyanide content. It further suggested that the amount of nutrient in the soil does not considerably contribute to the cyanogenic character of the cultivar. In Ethiopia, Endris (1977) [48] suggested that the cyanogenic content of cassava roots was significantly reduced by potassium application. In Nigeria, Okwu and Awurum (2001) [49] were able to prove that the value of $\mathrm{HCN}$ in the cassava samples decreases as fertilizer levels increases.

\section{Health Implications of Cyanide}

The toxicity of cyanogenic glycosides and their derivatives is dependent on the release of hydrogen cyanide. Toxicity may result in acute cyanide poisoning and has also been implicated in the etiology of several chronic diseases (FAO/WHO, 2012 [50]. Dietary exposure to elevated levels of some cyanogenic glycosides in food has the potential to cause acute cyanide poisoning or a debili- tating irreversible neurological condition in the long term.

High and sustained cyanogens intake at sub-lethal concentrations from cassava or cassava flour in combination with a low intake of sulfur amino acids has been reported to cause Konzo in women and children [5]. Konzo is an upper motor neuron disease characterized by irreversible but non-progressive symmetric spastic paraparesis that has an abrupt onset. It mostly affects children and women of childbearing age [42].

\section{Tropical Ataxic Neuropathy (TAN)}

It is another health problem associated with continuous consumption of improperly processed cassava products. TAN is used to describe several neurological syndromes attributed to toxiconutritional causes. TAN has occurred mainly in Africa, 
particularly Nigeria [52] and is common among people of 40 years and above (FSANZ, 2004). Dietary exposure to cyanide from the monotonous consumption of inadequately processed cassava products over years is responsible for the cause of the disease. Symptoms of TAN include sore tongue, optical atrophy, neuro sensory deafness, and sensory gait ataxia [52].

\section{Goiter and Cretinism}

They are common diseases in developing countries due to low intake of iodine $(<100 \mu \mathrm{g} /$ day $)$. The disease is particularly common in Africa because of their over dependent on cassava as a staple food. Continuous exposure to dietary cyanide from insufficiently processed cassava products aggravate the disease [53] by the interferences of thiocyanate (the end products of cyanide detoxification in human system) with dietary iodine, thus leading to iodine deficiency According to reference Rosling, 1987 [53], populations with very low iodine intake and high thiocyanate levels from consumption of cassava, showed severe endemic goiter, which decreases with iodine supplementation. Study has shown that consumption of cyanogenic glycosides even at a very low concentration can also cause iodine deficiency leading to goiter [54].

\section{Growth Retardation}

It is a common health problem especially among children in developing countries. Exposure to cyanogenic glycosides has been a contributing factor to this health problem. Growth retardation is particularly a serious problem in populations consuming foods with inadequate proteins especially diets that are low in sulfur containing amino acids (methionine and cysteine). This is because detoxification of cyanide in human body requires sulfur donors from sulfur-containing amino acids. Thus, dietary exposure to cyanide is a contributing factor to growth retardation [55].

\section{Cyanide Poisoning}

Cyanide toxicity occurs when cytochrome oxidase $\mathrm{a}_{3}$ inhibits the terminal enzyme in the respiratory chain and halts electron transport and oxidative phosphorylation (which is essential to the synthesis of Adenosine Triphosphate (ATP) and the continuation of cellular respiration) [56]. Cyanide poisoning occurs as a result of consumption of bitter cassava, almond kernels, or apricot kernels and their products without proper processing. Cases of cyanide poisoning after consumption of drink produced from the blends of apricot kernels and orange juice have been reported [57]. Clinical symptoms of cyanide toxicity are vomiting, nausea, dizziness, stomach pains, weakness, headache, diarrhea, and occasionally death $[14,38,58-60]$.

\section{Effect of Processing Cassava on Cyanide Content}

Cyanide in cassava can be found as bound glucosides, cyanohydrins, and free cyanide [61]. Each of the 3 forms has different toxicity and reacts differently to processing techniques that remove cyanide [62]. Thus, it is important to take into account the proportion of each cyanide form in the processed cassava. Many different processing techniques are used for cassava roots. Depending on the nature and duration of the processing methods, the residual level of cyanogens in cassava products will differ. Processing methods, such as peeling, drying, grinding, soaking, boiling or cooking, soaking and fermentation have been reported by several studies to cause significant reduction in the cyanogenic glycosides of processed foods. These processes can be applied to cassava roots to cause significant reduction in the cyanogen contents of the crops. Food-processing methods generally disintegrate cyanogens contents of plants, and this leads to the production of cyanide. Since cyanide is volatile, further processing techniques, such as roasting and drying, will volatilize the remaining cyanide to low level (Table 2).

\begin{tabular}{|c|c|c|}
\hline PROCESS & $\begin{array}{c}\text { RETENTION } \\
\%\end{array}$ & $\begin{array}{c}\text { CYANOGEN } \\
\text { GLYCOSIDE } \mathbf{~ m g} \\
\text { HCN/kg }\end{array}$ \\
\hline Fresh Root & 100 & 140 \\
\hline Boiling & 55.5 & 77.6 \\
\hline Steaming & 86.5 & 121 \\
\hline Frying & 89.3 & 125 \\
\hline Baking & 87.1 & 122 \\
\hline $\begin{array}{c}\text { Changing size boiling } \\
\text { (30 min) }\end{array}$ & & 160 \\
\hline Fresh Root & 100 & 41 \\
\hline 2-g pieces & 25.6 & 80 \\
\hline 5-g pieces & 50 & 120 \\
\hline 50-g pieces & 75 & 36.8 \\
\hline $\begin{array}{c}\text { Changing water ratio } \\
\text { boiling (30 min) }\end{array}$ & & 165 \\
\hline Fresh root & 100 & 60.5 \\
\hline Root: water (1: 1$)$ & 69.9 & 40.1 \\
\hline Root: water (1: 2) & 36.7 & \\
\hline Root: water (1: 5) & 24.2 & \\
\hline Root: water (1: 10$)$ & 22.3 & \\
\hline Cited from Nambisan and Sundaresan $(1985)$ [63]. Expressed as $\mu g$ \\
cyanide/g fresh weight in reference. \\
\hline
\end{tabular}

Table 2: Effects of different processing methods and boiling technique variations on cyanogen glucoside content of cassava roots.

\section{Boiling}

Boiling is not an effective method for cyanide removal $(50 \%)$. The inefficiency of this processing method is due to the high temperatures. At $100^{\circ} \mathrm{C}$, linamarase, a heat-labile $\beta$-glucosidase, is denatured and linamarin cannot then be hydrolyzed into cyanohydrin. Cooke and Maduagwu (1978) [62] reported that 
bound glucosides were reduced to $45 \%$ to $50 \%$ after $25 \mathrm{~min}$ of boiling. Free cyanide and cyanohydrin in boiled cassava roots are found at very low concentrations. Nambisan (1994) [64] reported a cyanohydrin and free cyanide content of $6 \%$ of the total cyanogens content in $50 \mathrm{~g}$ of boiled cassava roots, and only $3 \%$ in small pieces (2 g). Furthermore, Oke (1994) [65] reported that cyanohydrin and free cyanide were volatilized during boiling, which reduced the content in boiled cassava roots.

However, using small-sized cassava pieces or increasing the volume of water in which cassava roots are boiled can increase the efficiency of the boiling method (Table 2). For example by reducing cassava chip size, Nambisan and Sundaresan (1985) [63] demonstrated that boiling 2- and $50 \mathrm{-g}$ pieces of cassava root for 30 min resulted in a $75 \%$ and $25 \%$ reduction in cyanide content, respectively. Similarly, by increasing the volume of water from 1- to 5-fold, cyanogen retention was reduced from $70 \%$ to $24 \%$. Oke (1994) [65] reported that the solubilization of cyanogenic glucosides from the small cassava chips into the large volume of water seemed to better explain the cyanogen removal than enzymatic degradation.

\section{Steaming, Baking and Frying}

The loss of cyanide resulting from steaming, baking, or frying is small (Table 1) due to processing temperatures of over $100^{\circ} \mathrm{C}$ and to the stability of linamarin in neutral or weak acid conditions $[63,66]$. These methods are only suitable for sweet cassava, common in the South Pacific, because they contain low cyanide content [67].

\section{Drying}

Two kinds of drying are used for cassava: mechanical drying, such as in an oven, and natural drying by the sun. In the drying process, endogeneous linamarase controls the cyanogenic glucoside removal, and thus is responsible for cyanohydrin and free cyanide accumulation in dried cassava.

Generally, drying is not an efficient means of detoxification, especially for cassava varieties with high initial cyanogen glucoside content. In Tanzania, sun-drying whole roots into makopa reduced cyanide levels from 751 to $254 \mathrm{mg} \mathrm{HCN}$ equivalents $/ \mathrm{kg} \mathrm{DW}$, that is, $66 \%$ of total cyanogens were removed [39]. Cyanogenic glucoside breakdown during sun-drying depends on enzymatic hydrolysis and on gradual root cell disintegration. Thinner cassava pieces dry faster, and at low moisture content levels (13\%) linamarase is inactivated, and cyanogen glucoside break down ceases [39]. Cyanohydrin removal is increased with complete sun-drying. A possible explanation would be that dehydration of the roots and moisture losses results in $\mathrm{pH}$ changes, which affects cyanohydrin stability [39]. Because drying temperatures are above the boiling point of $\mathrm{HCN}\left(26^{\circ} \mathrm{C}\right)$ and free cyanide is easily released into the atmosphere, free cyanide can readily be removed [39].

\section{Fermentation}

Fermentation by lactic acid bacteria is a processing method commonly used in Africa. Fermentation is done with grated or soaked cassava roots and results in a decrease in $\mathrm{pH}$ value. The efficiency of the 2 kinds of fermentation differs due to the mechanisms of cyanogen removal. The microorganisms in the traditional fermentation process of grated roots have been characterized [68]. The fermentation of grated cassava roots is efficient at removing cyanogen glucosides. Westby and Choo (1994) [69] reported that $95 \%$ of linamarin was removed within 3 hours of grating. Vasconcelos and others (1990) [70] showed that microorganisms played only a small role in cyanogen reduction and that grating was mainly responsible for linamarin hydrolysis.

The process of roasting after fermentation of grated cassava, which is used for gari, is relatively efficient as free $\mathrm{HCN}$ and cyanohydrin are steadily removed into the atmosphere leaving little free $\mathrm{HCN}(3.4 \mathrm{mg} / \mathrm{kg} \mathrm{DW})$ and cyanohydrin $(2.2 \mathrm{mg} / \mathrm{kg} \mathrm{DW})$ [70]. Cyanide content of gari further decreases during storage. Indeed, Mahungu and others (1987) [71] showed that a 4-moold gari (2.9 mg HCN equivalents/kg) had a cyanogen content 9 times less than its initial content (26.6 mg HCN equivalents/ $\mathrm{kg}$ ), and after $2 \mathrm{y}$ of storage, gari seemed to be a cyanogen-free product, that is, in 57 samples analyzed, no cyanogen could be detected. The fermentation of soaked roots in water is much more effective than that of grated roots in terms of cyanogen reduction. Indeed, more than $90 \%$ of total cyanogens were removed after $3 \mathrm{~d}$ of fermentation and about one-third of initial linamarin was found in the water. No significant accumulation of cyanohydrin or free cyanide was noted [69]. In this case, microbial growth is essential for removing cyanogens. The cyanogen removal process can be improved by increasing the soaking and fermentation times [65] and by peeling and grating cassava roots between the soaking and fermentation stages.

\section{Other Processing Methods}

\section{Steam Distillation}

Meuser and Smolnick (1980) [72] showed that steam distillation of fresh cassava pulp resulted in total cyanogen removal for a minimum distillate volume of $100 \mathrm{~mL}$ (assumed to be normalized to $1 \mathrm{~kg}$ ). Steam distillation of fermented pulp slowly removed cyanogens. For a $100-\mathrm{mL}$ distillate volume, only $65 \%$ of cyanogens were removed. A distillate volume $\geq 550 \mathrm{~mL}$ was needed to remove about $90 \%$ of cyanogens. The resistance of fermented pulp to cyanogen removal can be explained by cyanohydrin stability at low $\mathrm{pH}$ values.

\section{Starch Production}

The process of starch extraction results in total cyanogen removal. Starch extraction involves different processing steps. 
First, cassava roots are grated or rasped, and then starch is extracted with a large volume of water; residues are emoved by sieving. In this way, a complete hydrolysis of cyanogenic glucosides occurs, and cyanohydrins, free cyanide, and the remaining cyanogenic glucosides solubilize in the supernatant water [63].

\section{Combination of Several Processing Methods}

To increase the efficiency of cyanogen removal, efficient processing techniques are usually combined with others that are less efficient. Sun-drying cassava roots usually retains about 25\% to $33 \%$ of total cyanogens. Nambisan (1994) [63] reported that boiling thin pieces of cassava roots in water for 5 to 10 min prior to sun-drying removed only $50 \%$ of cyanogenic glucoside content. However, if these pieces are further boiled in water, $50 \%$ of the remaining glucoside can be removed. Furthermore, if cassava roots are soaked before sun-drying, cyanogen removal is greater $(97.8 \%$ to $98.7 \%$ ) [65]. Soaking fresh cassava roots for 3 days followed by 3 days of drying resulted in the removal of $85.9 \%$ of total cyanogens. The flour of $f u f u$ obtained at the end of the process had $2.2 \%$ retention of total cyanogens [65]. Similarly, crushing and then sun-drying cassava roots into flour allowed a total cyanogen removal of $96 \%$ to $99 \%$ [63]. This last combination of processing steps is effective. Indeed, chinyanya, which is obtained after pounding and sun-drying fresh cassava roots for 1 day, retains $22 \%$ of total cyanogens, while makopa, which is obtained after sundrying whole cassava roots, retains $33 \%$ of total cyanogen [39]. In fact, crushing cassava roots damages the plant cells and, therefore, puts linamarase directly into contact with linamarin. Then, sundrying reduces cyanohydrin and free cyanide to low levels [73].

The fermentation process can be improved. Soaking, fermenting, and then roasting cassava roots into gari or farina reduces total cyanogen content to 1.8 to $2.4 \%$ in the final product [65]. Soaking and fermenting cassava roots for 3 days allows a reduction of total cyanogen content to 5.7\% [69]. Oke (1994) [65] reported that peeling and grating cassava before fermenting, and then sun-drying or oven-drying with moderate heat can result in a cyanogen-free product for any cassava variety that is used. Sun-drying for 6 hours instead of roasting for $10 \mathrm{~min}$ before fermenting for 2 days resulted in $22 \%$ less cyanogens.

\section{Comparison of the different Processing Techniques}

Methods involving grating and crushing are usually very efficient in cyanide removal because they completely rupture plant cells of cassava and allow direct contact between linamarase and linamarin [37,65]. However, sun-drying and heap fermentation are less efficient because peeled roots are usually cut in half longitudinally [37] and most of the plant cells remain intact. Hydrolysis of cyanogenic glucosides is prevented or reduced because linamarin and linamarase are located in different compartments of the plant cell. Heap fermentation retains half the cyanide of sun-drying because of the presence of microflora that can break down the linamarin during the fermentation process [74]. Boiling, which is relatively inefficient for removing cyanide $(50 \%)$, is much more efficient than baking, steaming, or frying ( $15 \%$ to $20 \%$ of cyanogen removal). Even if linamarase is inactivated at high temperatures $\left(100^{\circ} \mathrm{C}\right)$, cyanogens are watersoluble and, therefore, they can be removed during the dewatering process as in (Figure 2) below.

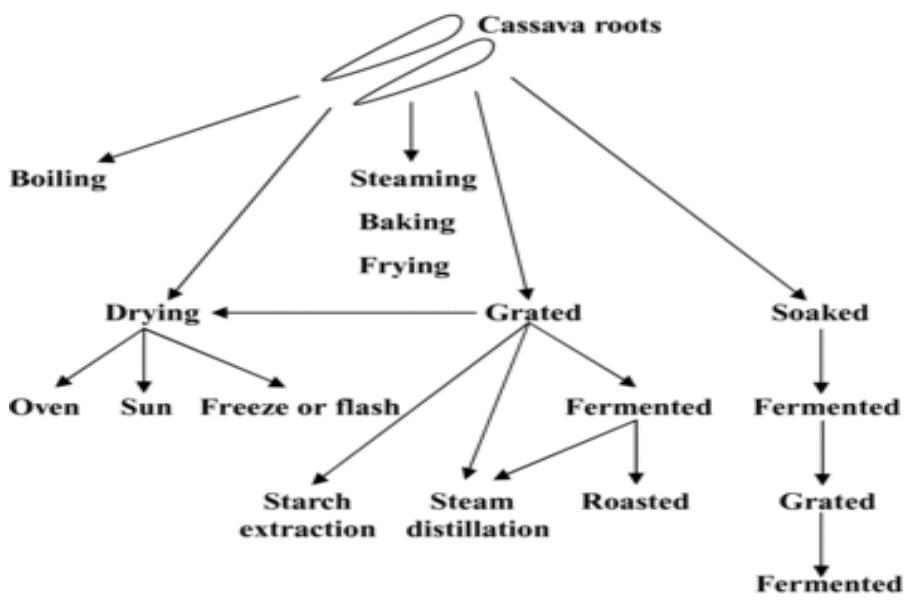

Figure 2: Cassava is processed in many different ways to be used in a variety of snacks and main dishes. Many times, the processing techniques are combined to either improve the end product or further reduce the amount of cyanide and/or phytate.

\section{Processed Cassava Foods Found on the Market}

Although efficient processing techniques to remove cyanide have been developed, many processed foods have a final cyanide content well above FAO/WHO's safe recommendation (1991) of 10 ppm. Oke (1994) [65] reported from work by cyanide content values of 0 to $32 \mathrm{ppm}$ in 202 gari samples from all over Nigeria (with a mean value of 6 ppm). Similarly, Adindu and others (2003) [75] reported that fufu, gari, and tapioca contained cyanide contents up to $30 \mathrm{ppm}$ on Nigerian markets, which is well above the safe value. These values are lower than the cyanide content of cassava flour in East Africa [37]. Indeed, Mlingi and Bainbridge (1994) reported values for cyanide contents of makiopa and chinyanya (sundried flours) to be above $130 \mathrm{ppm}$ in Tanzania. The values vary by geographic location and are usually related to the amount of cyanide present in the raw product.

Cardoso and others (2005) [37] developed an equation to predict differences in the total cyanide content of cassava root parenchyma and the processed food. Using this equation, they showed that to have cassava root flours with less cyanide than the WHO safe level, the roots should have a maximum content of 12 to $16 \mathrm{ppm}$ for sun-drying or 24 to $32 \mathrm{ppm}$ if roots were to undergo heap fermentation. Sun-drying and heap fermentation remove $67 \%$ to $75 \%$ and $83.5 \%$ to $87.5 \%$ of total cyanogens, respectively. Cardoso and others (1998) reported that flour 
produced by sun-drying and heap fermentation of cassava roots from markets in 3 areas of Mozambique contained 59 and $32 \mathrm{ppm}$ cyanide, respectively, which is higher than what is recommended. In cassava roots with high cyanogen content, processes sometimes are not sufficient to reduce levels of cyanide to $<10 \mathrm{mg} / \mathrm{kg}$. To produce safe cassava flour by sun-drying or heap fermentation, only sweet cassava roots with cyanide content $<32 \mathrm{ppm}$ should be used [37], which are more common in the South Pacific than Africa (Bradbury and Holloway 1988).

During drought years, total cyanide content of cassava roots increases, exacerbating the situation because traditional processing techniques may not adequately reduce the cyanide content of the cassava. Cardoso and others (2005) reported that the percentage of flour samples exceeding cyanide content of $100 \mathrm{ppm}$ increased in Mozambique from 6\% to $43 \%$ to $65 \%$ during low-rainfall years because of water stress. It is noteworthy that low rainfall is a common feature of the African climate. Therefore, other strategies are needed to reduce daily cyanide intake. One of these strategies could be the introduction of low-cyanide varieties of cassava.

\section{Safety Assessments}

Cyanogenic glycosides were assessed by the Joint FAO/ WHO Expert Committee on Food Additives (JECFA) in 1993 (Speijers, 1993) [76], by Food Standards Australia New Zealand (FSANZ) in 2004 (FSANZ, 2004) [30] and by the International Programme on Chemical Safety (IPCS) in 2004 (Simeonova and Fishbein, 2004) [15]. None of these assessments established a safe level of exposure to cyanogenic glycosides, mainly due a lack of quantitative toxicological and epidemiological information.

\section{Safety and Regulatory Limits}

Safety limits are levels of dietary exposure that are without appreciable risk for a lifetime of exposure. Regulatory limits define the maximum amount of a substance that is permitted in a particular food (FSANZ, 2004) (Table 3).

\begin{tabular}{|c|c|c|}
\hline Source & Limit Type & Limit \\
\hline \multicolumn{3}{|c|}{ Safety Limits } \\
\hline \multicolumn{3}{|c|}{ Regulatory Limits } \\
\hline \multicolumn{3}{|c|}{ Maximum Level Total hydrocyanic acid } \\
Co safety limits have been set for cyanogenic glycosides \\
\hline \multirow{3}{*}{$\begin{array}{c}\text { Australia, New } \\
\text { Zealand } \\
\text { Food } \\
\text { Standards } \\
\text { Code }\end{array}$} & Confectionery & $25 \mathrm{mg} / \mathrm{kg}$ \\
\cline { 2 - 3 } & Stone fruit drinks & $5 \mathrm{mg} / \mathrm{kg}$ \\
\cline { 2 - 3 } & Marzipan & $50 \mathrm{mg} / \mathrm{kg}$ \\
\cline { 2 - 3 } & Alcoholic beverages & $\begin{array}{c}1 \mathrm{mg} / \mathrm{kg} \mathrm{per} 1 \% \\
\text { alcohol }\end{array}$ \\
\hline
\end{tabular}

Table 3: Cyanide content approved regulatory limits by FSANZ.

\section{Conclusion}

Cyanogenic glycosides occur in cassava at variable levels. When cyanogenic glucosides undergo enzymatic hydrolysis hydrogen cyanide is liberated. Consumption of improperly processed cassava can lead to chronic and acute health problems as a result of cyanide poisoning. Understanding the appropriate processing methods for Cassava will help in reducing the problem of unintentional cyanide toxicity. Similarly, to prevent adverse effects of cyanogenic glycoside, consumers should prepare foods properly before consumption. This review presents the origin of hydrogen cyanide and its functions in cassava. Various processing methods and their effect on the levels of cyanide in cassava processed products were also reviewed.

\section{References}

1. Otusola BO (1991) Upgrading traditional cassava fermentation through processing improvement. In: Ofori F, Hahn S. K, (ed.). Accra Ghana. proceedings of the $9^{\text {th }}$ symposium of the international society for Tropical Root Crops-Africa Branch, Pg No: 261-266.

2. Otoo JA (1998) IITA: African wide cassava improvement programme. In: Praise of Cassava (ed.). Natalia DH, Ibandan, Nigeria: Proceedings of International Experts Group Meeting on the Exchange of Technology for Cassava Processing Engineering and Food Products, IITA Pg No: 67.

3. Ihenkoronye Al, Ngoddy PO (1985) Integrated Food Science and technology for the Tropics. London: Macmillan Publisher Ltd; Tropical roots and tuber crops Pg No: 384-389.

4. Nenna JE (1998) Food of Plant Origin. Nigeria: Afro-Orbits Publication Ltd; Roots and tubers Pg No: 137-139.

5. FSANZ (2004) Final assessment report proposal P257. Advice on the preparation of cassava and bamboo shoots. Report Number 2-04. Canberra: FSANZ.

6. (2001) FAO. (Food and Agriculture Organization of the United Nations) FAO Bulletin of Statistics, Rome, Italy. Bull Stat 2: 47-48.

7. Cereda MP, Mattos MCY (1996) Linamarin, the toxic compound of cassava. J Venom Anim Toxins 2.

8. Belloti A, Arias B (1993) The possible role of HCN on the biology and feeding behavior of the cassava rowing bug (Cyrtomenus bergi Froeschner). In: WM Roca, AM Thro, (ed.). Proceedings of the First International Scientific Meeting of the Cassava Biotechnology Network, Centro Internacional Agricultura Tropical, Cali, Colombia. Pg No. 406409.

9. Selmar D (1993) Transport of cyanogenic glycosides: uptake of linustatin by Hevea cotyledons. Planta 191: 191-199.

10. McMahon J, White W, Sayre RT (1995) Cyanogenesis in cassava (Manihot esculenta Crantz). J Exp Bot 46: 731-741.

11. Kakes P (1990) Properties and functions of the cyanogenic system in higher plants. Euphytica 48: 25-43.

12. Poulton JE (1990) Cyanogenesis in plants. Plant Physiol 94: 401405. 
13. KendeH(1989)Enzymes of ethylene biosynthesis. PlantPhysiol91:1-4.

14. Haque MR, Bradbury JH (2002) Total cyanide determination of plants and foods using the picrate and acid hydrolysis methods. Food Chemistry $77: 107-114$.

15. Simeonova FP, Fishbein L (2004) Hydrogen cyanide and cyanides: Human health aspects. Concise International Chemical Assessment Document 61. Geneva: World Health Organization.

16. Poulton JE (1989) Toxic compounds in plant foodstuffs: cyanogens. In: JE Kinsella, WG Soucie, (eds.). Food Proteins.The American Oil Chemists' Society, Champaign, IL. Pg No: 381-401.

17. Poulton JE, (1988) Localization and Catabolism of Cyanogenic Glycosides. In: Cyanide Compunds in Biology. Rvered D and Harnett S. (eds.) John Wiley \& Sons: Chichester, UK. Pg No: 67-71.

18. Kojima M, Poulton JE, Thayer SS, Conn EE (1979) Tissue distributions of dhurrin and of enzymes involved in its metabolism in leaves of Sorghum bicolor. Plant Physiol 63: 1022- 1028.

19. Kojima M, Iwatsuki N, Data ES, Villegas CDV, Uritani I (1983) Changes of cyanide content and linamarase activity in wounded cassava roots. Plant Physiol 72: 186-189.

20. Frehner M, Conn EE (1987) The linamarin-glucosidase in Costa Rican wild lima beans (Phaseolus lunatus L.) is apoplastic. Plant Physiol 84: 1296-1300.

21. Nahrstedt A (1985) Cyanogenic compounds as protecting agents for organisms. Plant Syst Evol 150: 35-47.

22. Cock JH (1985) Cassava: New Potential for a Neglected Crop. Westfield Press, London.

23. South Pacific Trade Commission. Exporting Fruit and Vegetables to New Zealand, A Guide for Pacific Island Producers. Auckland, New Zealand. 2000.

24. Bokanga M, Ekanayake IJ, Dixon AGO, Porto MCM (1994) Genotype -environment interac - tions for cyanogenic potential in cassava. Acta Hort 375: $131-139$.

25. Bolarinwa IF, Olaniyan SA, Olatunde SJ, Ayandokun FT, Olaifa IA (2016) Effect of processing on amygdalin and cyanide contents of some Nigerian Foods. J Chem Pharm Res 8: 106 -113.

26. Lykkesfeldt J, Moller BL (1994) Cyanogenic glycosides in cassava, Manihot esculenta Crantž̌ Acta Chem Scanda 48: 178 -180.

27. Gomez G, Valdivieso M (1983) The effect of variety and plant age on cyanide content, chemical composition and quality of cassava roots. Nutrition Reports International 27: 857-865.

28. Fomunyam RT, Adegbola AA, Oke OL (1984) Hydrolysis of linamarin by intestinal bacteria. Canadian Journal of Microbiology 1530-3330.

29. Aregheore E.M, Agunbiade OO (1991) "The toxic effects of cassava (Mannihot esculenta crantz) diets on humans: a review". Vet. Human Toxicology 33: 274-275.

30. Riis L, Bellotti AC, Bonierbale M, O'Brien GM (2003) Cyanogenic potential in cassava and its influence on a generalist insect herbivore (Cyrtomenus bergi Hemiptera: Cydnidae). J Econ Entomol 96: 1905 -1914.

31. Nambisan B (2011) Strategies for elimination of cyanogens from cassava for reducing toxicity and improving food safety. Food Chem Toxicol 49: 690 -693.
32. Siritunga D, Sayre RT (2000) Generation of cyanogen -free transgenic cassava. Planta 217: $367-373$.

33. Wobeto C, Correa AD, De Abreu CMP, Dos Santos CD, Pereira HV (2007) Anti -nutrients in the cassava (Manihot esculenta Crantz) leaf powder at three ages of the plant. Cien Technol Aliment 27: $108-112$.

34. FAO/WHO (1991) Joint FAO/WHO Food Standards Programme. Codex Alimentarius Commission XII, Supplement 4, FAO, Rome, Italy.

35. Damardjati DS, Widowati S, Rachim A (1993) Cassava flour production and consumer's acceptance at village level in Indonesia. Indonesian Agricultural Research and Development Journal 15: 16-25.

36. Djazuli M, Bradbury JH (1999) Cyanogen content of cassava roots and flour in Indonesia. Food Chemistry 65: 523-525.

37. Cardoso AP, Mirione E, Ernesto M, Massaza F, Cliff J, et al. (2005) Processing of cassava roots to remote cyanogens. J Food Comp Anal 18: $451-460$.

38. Mlingi N, Poulter NH, Rosling $\mathrm{H}$ (1992) An outbreak of acute intoxications from consumption of insufficiently processed cassava in Tanzania. Nutrition Research 12: 677-687.

39. Mlingi NLV, Bainbridge $Z$ (1994) Reduction of cyanogen levels during sun-drying of cassava in Tanzania. Acta Horticulturae 375: 233-239.

40. Akintonwa A, Tunwashe O, Onifade A (1994) Fatal and non-fatal acute poisoning attributed to cassava-based meal. ActaHorticulturae 375 : 285-288.

41. Onabolu AO, Oluwole OS, Bokanga M, Rosling H (2001) Ecological variation of intake of cassava food and dietary cyanide load in Nigerian communities. Public Health Nutrition 4: 871-876.

42. Ernesto M, Cardoso AP, Nicala D, Mirione E, Massaza F, et al. (2002) Persistent konzo and cyanide toxicity from cassava in Northern Mozambique. Acta Trop 82: 357-362.

43. Wheately CC, Orrego JI, Sanchez T, Granados E (1993) Quality evaluation of cassava core collection at CIAT. In: Roca AM Thro AM, (ed.). Proceedings of the First International Scientific Meeting of Cassava Biotechnology Network; CIAT, Cali Columbia. Pg No: 379-383.

44. Aalbersberg WGL, Limalevu L (1991) Cyanide content in fresh and processed Fijian cassava (Manihot esculenta) cultivars. Trop. Sci 31: 249-256.

45. Gitebo DN, Banea-Mayabu JP, Matadi RN, Tylleskar T, Gebre-Medhin M, et al. (2009) Geogarphical and Seasonal Association between Linamarin and Cyanide Exposure from Cassaca and the upeer motor neuron disease Konzo in DRC. In CCDN News.

46. Splittstoesser EE, Tunya GO (1992) Crop Physiology of Cassava; In Horticulture Reviews (ed.). Janick J 102-127.

47. Rolinda L, Talatala RL, Ma TP, Loreto I (2008) Cyanide Content of Cassava Cultivars at Different Fertility Levels and Stages of Maturity. Department of Science and Technology Region 10.

48. Endris S (1977) Cyanogenic potential of cassava cultivars grown under varying levels of potassium nutrition in Southwestern Ethopia. Ethiopian Institute of Agricultural Research (EIAR), Jimma Center, PO Box 192, Jimma.

49. Okwu DE, Awurum AN (2001) Journal of Applied Chemistry and Agricultural Research 7: 112-119. 
50. (2012) FAO/WHO. WHO Food Additive Series: 65. Safety evaluation of certain food additives and contaminants. Prepared by the 74th Meeting of the Joint FAO/WHO Expert Committee on Food Additives (JECFA) World Health Organization, Geneva.

51. Tylleskar T, Banae M, Bikangi N, Cooke RD, Poulter NH, et al. (1992) Cassava cyanogens and konzo, an upper motorneuron disease found in Africa. Lancet 339: 208 -211.

52. Oluwole OSA, Onabolu AO, Link H, Rosling H (2000) Persistence of tropical ataxic neuro - pathy in a Nigerian community. J Neurol Neurosurg Psychiatry 69: $96-101$.

53. Rosling H (1987) Cassava Toxicity and Food Security. (ed.). Rosling Tryck Kontakt, Uppsala, Sweden. Pg No: 3 -40.

54. Odo CE, Enechi OC, Oburu CS (2014) Concentrations of anti -nutritional factors in raw edible cocoyam (Colocasia esculenta) leaves. J Pharm Res 8: 38 -40.

55. Banea -Mayambu JP, Tylleskar, T, Tylleskar K, Gebre -Medhin M, Rosling H (2000) Dietary cyanide from insufficiently processed cassava and growth retardation in children in the Democratic Republic of Congo (formerly Zaire). Ann Trop Pediatr 20: 34 -40.

56. Hamel J (2011) A review of acute cyanide poisoning with a treatment update. Crit Care Nurse 31: 72 -82.

57. Atkinson K (2006) Apricot kernels carry risk of cyanide poisoning.

58. Lash EE, Shawa RE (1981) Multiple cases of cyanide poisoning by apricot kernels in children from Gaza. Pediatrics 68: 5 -7.

59. Akyildiz BN, Kurtoğlu S, Kondolot M, Tunç A (2010) Cyanide poisoning caused by ingestion of apricot seeds. Ann Trop Paediatr 30: 39 -43.

60. Sanchez -Verlaan P, Geeraerts T, Buys S, Ruy -Poulenc B, Cabot C, et al. (2011) An unusual cause of severe lactic acidosis: cyanide poisoning after bitter almond ingestion. Intens Care Med 37: 168 -169.

61. Cooke RD (1983) Effect of cassava processing on residual cyanide. In: DalangeF, AlhluwaliaA, (ed.). Cassava toxicity and thyroid; research and public health issues; Proceedings of Workshop. Ottawa: IDRC-207c.

62. Cooke RD, Maduagwu E (1978) The effects of simple processing on the cyanide content of cassava chips. J Food Technol 13: 299-306.

63. Nambisan B, Sundaresan S (1985) Effect of processing on the cyanoglucoside content of cassava. J Sci Food Agric 36: 1197-203.
64. Nambisan B (1994) Evaluation of the effect of various processing techniques on cyanogen content reduction in cassava. Acta Hortic 375: 193-201.

65. Oke OL (1994) Eliminating cyanogens from cassava through processing: technology and tradition. Acta Hortic 375: 163-74.

66. Bradbury JH, Egan SV, Lynch MJ (1991) Analysis of cyanide in cassava using acid hydrolysis of cyanogenic glucosides. J Sci Food Agric 55: $277-290$.

67. Bradbury JH, Holloway WD (1988) Cassava, M. esculenta. Chemistry of tropical root crops: significance for nutrition and agriculture in the pacific. Australian Centre for International Agricultural Research, Canberra, Australia. Pg No: 76-104.

68. Coulin P, Farah Z, Assanvo J, Spillmann H, Puhan (2006) Characterisation of the microflora of attiéké, a fermented cassava product, during traditional small-scale preparation. Int J Food Microbiol 106: 131-136.

69. Westby A, Choo BK (1994) Cyanogen reduction during lactic fermentation of cassava. Acta Hortic 375: 209-15.

70. Vasconcelos AT, Twiddy DR, Westby A, Reilly PJA (1990) Detoxification of cassava during gari preparation. Int J Food Sci Technol 25: 198-203.

71. Mahungu NM, Yamaguchi Y, Alamazan AM, Hahn SK (1987) Reduction of cyanide during processing of cassava into some traditional African foods. J Food Agric (Nigeria) 1: 11-15.

72. Meuser F, Smolnick HD (1980) Processing of cassava to gray and other foodstuffs. Starch/Starke 32: 116-122.

73. Heuberger C (2005) Cyanide content of cassava and fermented products with focus on attiéké and attiéké garba. Diss. ETH No. 16247. Dissertation submitted to the Swiss Federal Institute of Technology, Zurich, for the degree of Doctor of Natural Sciences.

74. Padmaja G (1989) Evaluation of techniques to reduce assayable tannin and cyanide in cassava leaves. J Agric Food Chem 37: 712-716.

75. Adindu MN, Olayemi FF, Nze-Dike OU (2003) Cyanogenic potential of some cassava products in Port Harcourt markets in Nigeria. J Food Comp Anal 16: 21-24.

76. Speijers G (1993) Cyanogenic glycosides. Food Additive Series No. 30. Geneva: JECFA. 